\title{
Peran Mahasiswa Kampus Mengajar 2 Sebagai "Agent Of Change dan Social Control"
}

\author{
Yorri Didit Setyadi*1, Dwi Wulandari², Lutfi Dwi Lestari³, Wa Ode Meliasari ${ }^{4}$, Ifit Novita Sari*5 \\ 1Program Studi Pendidikan Bahasa Mandarin, Fakultas Bahasa dan Seni, Universitas Negeri Surabaya \\ 2,3,4Program Studi Pendidikan Guru Sekolah Dasar, Fakultas Psikologi dan Ilmu Pendidikan, \\ Universitas Muhammadyah Sidoarjo \\ ${ }^{5}$ Program Studi Pendidikan Bahasa dan Sastra Indonesia, Fakultas Keguruan dan Ilmu Pendidikan, \\ Universitas Islam Malang \\ *e-mail: yorri.18069@mhs.unesa.ac.id 1, dwiwulansari69@gmail.com²,lutfilestari15@gmail.com³, \\ waodemeliasari99@gmail.com4, inovsari@unisma.ac.id 5
}

\begin{abstract}
Abstact
Students are the assets of a nation because students are a group of people trained in various fields of knowledge and skills. State Junior High School 2 Tanggulangin s one of the target schools selected by the author and Ministry of Education and Culture as the place for the Kampus Mengajar $2^{\text {nd }}$ Generation as the student change agent of the education program created by us, among them the implementation of literacy learning activities and student numeration aimed at improving the understanding of literacy and student numeration. Social control is a tool to control himself or society. In this case, the society underneath is the entire State Junior High School 2 Tanggulangin and students as the main object of Kampus Mengajar $2^{\text {nd }}$ Generation activities.
\end{abstract}

Keywords: Agent of Change, Social Control, Student of Kampus Mengajar

\begin{abstract}
Abstrak
Mahasiswa merupakan asset suatu bangsa karena mahasiswa adalah sekelompok orang yang terlatih dalam berbagai bidang ilmu pengetahuan dan keterampilan. SMPN 2 Tanggulangin merupakan salah satu sekolah sasaran yang dipilih oleh kemendikbud sebagai tempat untuk mahasiswa Kampus Mengajar Angkatan 2 ditugaskan yang diharapkan untuk menjadi agen perubahan. Sebagai agen perubahan mahasiswa program pendidikan yang telah diwujudkan oleh Mahasiswa Kampus Mengajar Angkatan 2 diantaranya pelaksanaan kegiatan pembiasaan literasi dan numerasi siswa yang bertujuan untuk meningkatkan pemahaman literasi dan numerasi siswa. Social control yaitu sebagai alat untuk mengontrol dirinya sendiri maupun masyarakat. Dalam hal ini masyarakat yang digaris bawahi adalah seluruh warga SMPN 2 Tanggulangin dan siswa sebagai objek utama dari sasaran kegiatan Kampus Mengajar 2.
\end{abstract}

Kata kunci: Agent of Change, Social Control, Mahasiswa Kampus Mengajar

\section{PENDAHULUAN}

Pendidikan merupakan salah satu hal yang penting dalam mengarahkan suatu perubahan bagi bangsa untuk menuju ke yang lebih baik. Tanpa adanya pendidikan maka suatu bangsa bisa dikatakan mustahil bisa berdiri sendiri dan memperoleh sesuatu hal yang diharapkan. Pendidikan yang baik akan membawa suatu perubahan yang baik bagi bangsa maka dibutuhkan suatu pendidikan yang baik dengan adanya dukungan baik dari pemerintah maupun dari masyarakat bangsa itu sendiri, generasi muda terdidik yang memiliki pengaruh dalam mesyarakat yakni mahasiswa. Sebagai kaum intelektual dan anggota mayarakat yang punya nilai tambah, mahasiswa untuk mampu memperankan diri secara profesional dan proporsional di masyarakat ataupun di dunia pendidikan. Perlu pengembangan metode pembelajaran yang menarik minat dan bakat mahasiswa untuk lebih berkarya (Putri, 2018).

Peran mahasiswa tidak sekedar kegiaan pembelajaran di bangku perkuliahan, di perpustakaan dan akses internet yang ada hubungangannya dengan disiplin ilmu yang sedang ia tempuh tapi lebih dari itu. Mahasiswa merupakan asset suatu bangsa karena mahasiswa adalah sekelompok orang yang terlatih dalam berbagai bidang ilmu pengetahuan dan keterampilan karena itulah mengapa ungkapan "Student today, leader tomorrow" terasa tidak berlebihan. Sebagai generasi muda, mahasiswa akan menjadi generasi penerus bangsa dalam menghadapi perkembangan masyarakat yang semakin pesat dan sangat rumit, maka mahasiswa menjadi 
generasi penerus bangsa yang harus mampu menghadapi berbagai perubahan dan masalah yang ditimbulkan perubahan itu sendiri untuk menjawab tantangan perubahan yang ada. (Istichomaharani \& Habibah, 2016)

Mahasiswa adalah sekelompok intelektual muda dalam masyarakat, yang tentunya mengetahui berbagai fasilitas masyarakat yang disediakan oleh pemerintah, mahasiswa memiliki tanggung jawab moral terhadap fasilitas tersebut karena masyarakat didanai oleh uang rakyat. Karena itu Salah satu kewajiban mahasiswa adalah mengabdikan diri pada waktu kuliah mereka untuk mencari perbaikan di masyarakat sekitar. Misalnya, mengikuti kegiatan yang melibatkan kerjasama antara Kementerian Pendidikan Kebudayaan Riset dan Teknologi dengan Perguruan Tinggi yakni dalam program Kampus Merdeka.

Kampus Merdeka merupakan program Kemendikbudristek yang menawarkan kesempatan bagi mahasiswa dan juga mahasiswi Indonesia untuk mengasah kemampuan sesuai bakat dan minat mereka dengan terjun langsung ke dunia kerja. Dengan mengikuti berbagai program yang disediakan, mahasiswa diharapkan dapat mengembangkan potensinya sesuai dengan passion dan bakat yang dimiliki secara lebih fleksibel. Dari berbagai macam program yang disediakan oleh kampus mengajar, salah satu program yang dapat mengembangkan skill mengajar yakni program kampus mengajar. (Neneng Zubaidah, 2021)

Pada praktiknya, program Kampus mengajar adalah kegiatan mengajar di sekolah yang merupakan bagian dari program Kampus Merdeka. Menteri Pendidikan dan Kebudayaan (Mendikbud), Nadiem Anwar Makarim menjelaskan, tujuan diselenggarakannya Kampus Mengajar ini terutama untuk mengenalkan mahasiswa sebagai bagian dari peningkatan pembelajaran membaca, berhitung dan berdaptasi dengan teknologi. Kedua, membantu pembelajaran di masa pandemi khususnya untuk SD dan SMP 3T. Pelaksanaan program ini sendiri didukung oleh Lembaga Pengelola Dana Pendidikan (LPDP), program ini memberikan peluang baik untuk melatih dan mengembangkan skill mengajar mahasiswa sekaligus dapat mengembangkan diri. Dalam program ini, peran mahasiswa yakni menjadi mitra guru dalam pembelajaran literasi, numerasi dan adaptasi teknologi untuk jenjang SD dan SMP. (Kementerian \& Kebudayaan, 2021)

Faktanya, dalam program Kampus Mengajar peran mahasiswa tidak hanya sebagai mitra guru melainkan sebagai agen perubahan, sosial kontrol dan iron stock dalam sekolah. Mahasiswa memiliki tempat tersendiri di lingkungan sekolah, namun bukan berarti memisahkan diri dari warga sekolah. Oleh karena itu perlu dirumuskan perihal peran, fungsi, dan posisi mahasiswa untuk menentukan arah perjuangan dan kontribusi mahasiswa tersebut. Peran penting mahasiswa yang merupakan harapan dari sekolah yakni peran sebagai agent of change, social control dan iron stock. Mahasiswa menjadi agen pemberdayaan setelah perubahan yang berperan dalam pembangunan fisik dan non fisik sebuah bangsa yang kemudian ditunjang dengan fungsi mahasiswa selanjutnya yaitu social control, kontrol budaya, kontrol masyarakat, dan kontrol individu. Mahasiswa bukan sebagai pengamat dalam peran ini, namun mahasiswa juga dituntut sebagai pelaku dalam lingkungan sekolah. (Cahyono et al., 2019)

Maka dari itu program Kampus Mengajar Angkatan 2 merupakan salah satu dari tiga unsur Tri Dharma Perguruan Tinggi yaitu Pendidikan, Penelitian, dan Pengabdian. Kegiatan ini merupakan wahana mengamalkan ilmu pengetahuan yang dimiliki. Sehingga keberadaan mahasiswa di SMPN 2 Tanggulangin dapat memberikan manfaat, khususnya sebagai Agen Perubahan dan Sosial Kontrol.

\section{HASIL DAN PEMBAHASAN}

\section{Agent of Change}

Perubahan disemua bidang kehidupan yang sangat cepat dan signifikan telah mengakibatkan perubahan sosial yang harus dibarengi dengan perubahan ilmu pengetahuan dan kemajuan teknologi. Oleh karena itu, perubahan sosial adalah keniscayaan karena tidak ada 
masyarakat yang tidak berubah (Idris, 2013). Menurut (Amalia et al., 2017) bahwa Agent of change adalah orang yang membantu membuat perubahan. (Anwar \& Utama, 2014) menyatakan seorang agen perubahan akan menghubungkan objek perubahan (inovasi, kebijakan publik, dll.) dengan sistem sosial yang menjadi objek perubahan. Tentu saja, pendidikan memegang peranan yang sangat penting dalam mengatasi perubahan tersebut.

Pendidikan akan memberikan panduan yang jelas tentang bagaimana menanggapi perubahan. Jika pendidikan menjadi pusat perubahan tersebut, tampaknya perubahan tersebut dapat berhasil dilalui dan dijadikan landasan untuk mewujudkan pembangunan seluruh rakyat Indonesia. Mahasiswa sebagai agen perubahan perlu memiliki kepekaan sosial (social selfawareness) yang tinggi dan menjadi pembicara pendamping dalam kegiatan pengabdian kepada masyarakat. Hal ini menjadikan hakikat tanggung jawab seorang mahasiswa dan dosen secara jelas tertuang dalam Tri Dharma Perguruan Tinggi. Desmira (2021:409) mengemukakan bahwa misi mahasiswa adalah menuntut ilmu, meneliti dan mengabdi kepada masyarakat (Desmira, 2021).

Mahasiswa Kampus Mengajar Angkatan 2 merupakan sosok agen perubahan pada SMPN 2 Tanggulangin. Ada beberapa program pendidikan yang telah diwujudkan oleh Mahasiswa Kampus Mengajar, diantaranya pelaksanaan kegiatan pembiasaan literasi dan numerasi siswa yang bertujuan untuk meningkatkan pemahaman literasi dan numerasi siswa. Sesuai dengan penelitian (Ekowati et al., 2019) bahwa Kemampuan literasi numerasi didefinisikan sebagai kemampuan individu untuk menggunakan penalaran. Penalaran berarti menganalisis dan memahami suatu pernyataan melalui tindakan memanipulasi simbol atau bahasa matematika yang ditemukan dalam kehidupan sehari-hari, dan mengungkapkan pernyataan tersebut secara tertulis atau lisan. Dengan adanya program ini, siswa akan terbiasa dengan membaca secara keseluruhan sehingga akan mengurangi adanya berita hoax yang beredar, Menurut (Mulyo Teguh, 2017) Gerakan Literasi Sekolah tidak terbatas pada membaca dan menulis, tetapi mencakup keterampilan berpikir dalam hal tahapan dan komponen literasi. Semua proses pembelajaran didasarkan pada kemampuan membaca. Dengan keaksaraan yang tertanam dalam diri setiap anak, tingkat pencapaian yang lebih tinggi di sekolah dan di masyarakat membuka pintu menuju kesuksesan yang lebih besar dalam hidup. Pada kegiatan numerasi bertujuan untuk meningkatkan kemampuan berhitung yang akan digunakan dalam kehidupan sehari-hari. Dengan adanya kegiatan literasi numerasi yang diterapkan pada peserta didik SMPN 2 Tanggulangin ini memiliki banyak perubahan yang awalnya peserta didik memiliki kemampuan yang rendah dengan ditandai nilai yang dibawah rata-rata menjadi memiliki kemampuan yang tinggi dan memiliki nilai yang baik.

Kegiatan yang dilaksanakan oleh Mahasiswa Kampus Mengajar berikutnya adalah mengadakan lomba memperingati hari kemerdekaan secara virtual karena adanya pandemi Covid-19 yang meminimalisir kegiatan bertatap muka yang mengundang banyak kerumunan seperti biasanya sehingga agar kegiatan tetap berjalan dengan lancar dan tetap mematuhi protokol kesehatan untuk tetap menjaga jarak sebagai upaya mencegah rantai penularan Covid19, Mahasiswa Kampus Mengajar membuat kegiatan lomba secara virtual dengan memanfaatkan teknologi yang ada, beberapa kegiatan tersebut sebagai berikut : Lomba fotografi, lomba puisi, lomba menyanyi, lomba Tarik tambang online, dan lomba cerdas cermat. Dengan adanya kolaborasi yang kompak antara Mahasiswa Kampus Mengajar dengan OSIS sekolah kegiatan ini berjalan dengan lancar dan banyak peserta didik yang berpartisipasi dalam perlombaan ini. Mahasiswa Kampus Mengajar mendesain jenis perlombaan yang menarik dan berbeda dengan sebelumnya agar banyak peserta didik yang mengikutinya. Dengan adanya peran Mahasiswa, kegiatan ini mengalami banyak perubahan yang jauh lebih baik dari tahun sebelumnya, dimana partisipasi kegiatan memperingati hari kemerdekaan pada tahun sebelumnya hanya satu hingga 2 orang saja, tetapi dengan adanya Mahasiswa kegiatan ini diikuti sekitar 150 orang. 


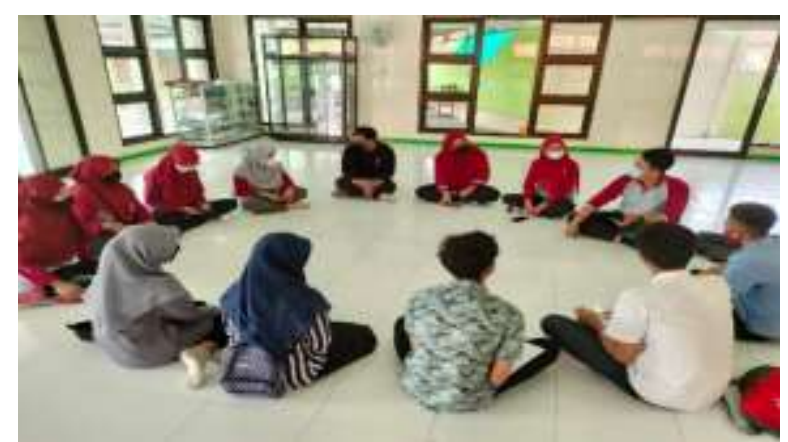

Gambar 1. Diskusi antara Mahasiswa Kampus Mengajar dengan Siswa OSIS terkait Kegiatan 17 Agustus

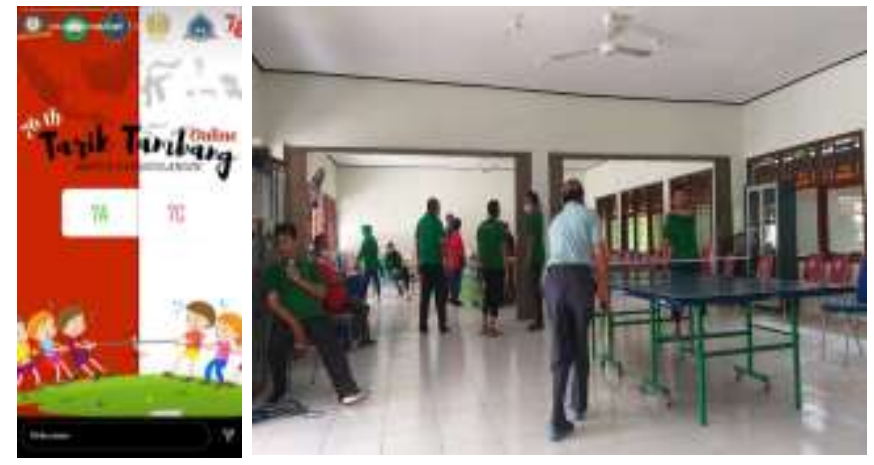

Gambar 2. Kegiatan 17 Agustus

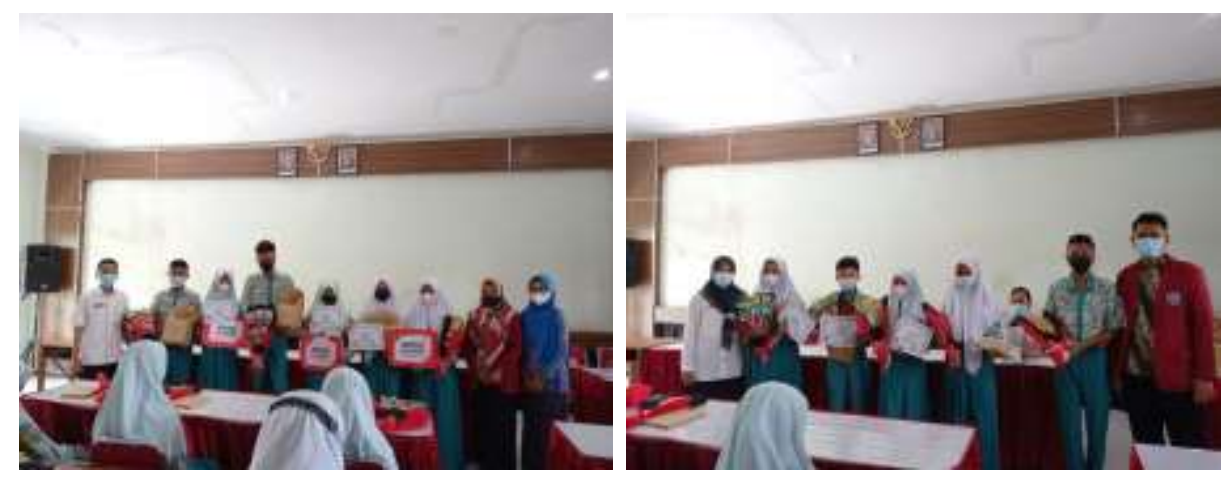

Gambar 3. Pembagian Hadiah Pemenang Lomba 17 Agustus

\section{Social Control}

Mahasiswa kampus mengajar sebagai agen perubahan yang dibutuhkan oleh sekolah terutama dikarenakan saat ini dunia sedang mengalami masa pandemi virus Covid-19 atau yang disebut dengan Coronavirus. Banyak perubahan besar terjadi mulai dari kehidupan masyarakat yang lebih dibatasi, hal ini tak luput dengan dunia pendidikan yaitu sekolah yang berada pada 3T (tertinggal, terdepan, terluar) yang tersebar pada setiap daerah di Indonesia.

SMPN 2 Tanggulangin merupakan salah satu sekolah sasaran yang dipilih oleh kemedikbud sebagai tempat untuk mahasiswa kampus mengajar 2 ditugaskan yang diharapkan untuk menjadi agen perubahan. Puariestahufani dalam (La Ode Alis, Jamaluddin, 2018) Mahasiswa memiliki andil pada negaranya dengan melakukan prestasi dalam akademik maupun non-akademik sebagai bentuk kecintaan kepada Indonesia. Social control yaitu sebagai alat untuk mengontrol dirinya sendiri maupun masyarakat. Dalam hal ini masyarakat yang digaris bawahi adalah seluruh warga SMPN 2 Tanggulangin dan siswa sebagai objek utama dari sasaran kegiatan Kampus Mengajar 2. Selama pandemi berlangsung dari yaitu bulan Februari 2020 - saat ini yaitu Desember 2021, kegiatan disekolah perlahan-lahan membenahi kegiatan belajar mengajar dari mulai melakukannya melalui daring dengan menggunakan aplikasi video confrence sampai social media. Namun kendala yang terjadi di SMPN 2 Tanggulangin adalah dikarenakan mayoritas siswanya kurang mampu maka model pembelajaran ini tidak berjalan dengan baik, maka disaat 
perizinan untuk sekolah melakukan tatap muka terbuka peran mahasiswa untuk membantu para siswa untuk meningkatkan semangat belajar dan aktif kembali seperti sebelum adanya pandemi.

Kegiatan kontrol sosial disekolah yang sudah dilakukan yaitu. Pertama, adalah memberikan penyuluhan tentang kegiatan PHBS (perilaku hidup bersih dan sehat) yang bertuhuan untuk memberikan pengetahuan kepada siswa, guru, dan staff sekolah karena permasalahan virus Covid-19 saat ini adalah masalah serius yang perlu dihadapi oleh semua orang terutama adalah tentang ciri-ciri orang yang terpapar virus Covid-19 yang memilki gejala seperti virus influenza biasa tetapi virus ini lebih mematikan dampaknya Yunus dan Annissa pada (Fristiohady, 2021:181), yang kedua adalah membantu dalam kegiatan tatap muka terbatas yang telah dilaksanakan dengan mengingatkan selalu memakai masker, mencuci tangan dengan sabun dan handsanitizer, menjaga jarak, memberitahu ke guru bila dirasa kurang enak badan. Ketiga adalah menjadi teman konseling kepada siswa yang sedang mengalami masalah seperti kesulitan belajar, kurangnya motivasi untuk belajar, dan juga adanya masalah dalam pergaulan siswa (Fristiohady, 2020).
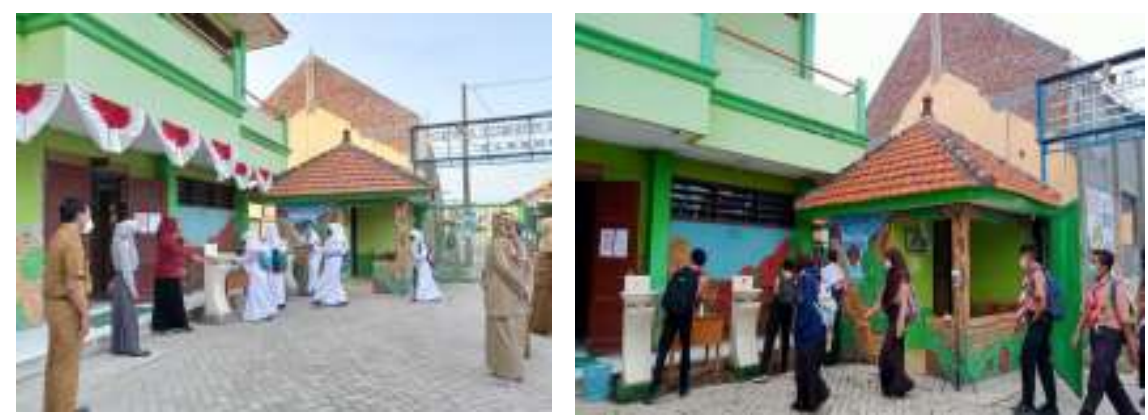

Gambar 4. Perilaku Hidup Bersih dan Sehat selama pembelajaran Tatap Muka Terbatas

\section{KESIMPULAN}

Pendidikan yang baik akan membawa suatu perubahan yang baik bagi bangsa. Peran mahasiswa tidak sekedar kegiatan pembelajaran di bangku perkuliahan, di perpustakaan dan akses internet yang ada hubungangannya dengan disiplin ilmu yang sedang ia tempuh tapi lebih dari itu. Mahasiswa merupakan asset suatu bangsa karena mahasiswa adalah sekelompok orang yang terlatih dalam berbagai bidang ilmu pengetahuan dan keterampilan karena itulah mengapa ungkapan "Student today, leader tomorrow" terasa tidak berlebihan. Pendidikan menjadi pusat perubahan tersebut, tampaknya perubahan tersebut dapat berhasil dilalui dan dijadikan landasan untuk mewujudkan pembangunan seluruh rakyat Indonesia. Salah satunya peran dari Mahasiswa Kampus Mengajar Angkatan 2 merupakan sosok agen perubahan pada SMPN 2 Tanggulangin. Ada beberapa program pendidikan yang telah diwujudkan oleh Mahasiswa Kampus Mengajar, diantaranya pelaksanaan kegiatan pembiasaan literasi dan numerasi siswa yang bertujuan untuk meningkatkan pemahaman literasi dan numerasi siswa. Dengan adanya kegiatan literasi numerasi yang diterapkan pada peserta didik SMPN 2 Tanggulangin ini memiliki banyak perubahan yang awalnya peserta didik memiliki kemampuan yang rendah dengan ditandai nilai yang dibawah rata-rata menjadi memiliki kemampuan yang tinggi dan memiliki nilai yang baik.

Mahasiswa memiliki andil pada negaranya dengan menghasilkan prestasi dalam akademik maupun non-akademik sebagai bentuk kecintaan kepada Indonesia. Social control yaitu sebagai alat untuk mengontrol dirinya sendiri maupun masyarakat. Dalam hal ini masyarakat yang digaris bawahi adalah seluruh warga SMPN 2 Tanggulangin dan siswa sebagai objek utama dari sasaran kegiatan Kampus Mengajar 2. Selama pandemi berlangsung dari yaitu bulan Februari 2020 - saat ini yaitu Desember 2021, kegiatan disekolah perlahan-lahan membenahi kegiatan belajar mengajar dari mulai melakukannya melalui daring dengan menggunakan aplikasi video confrence sampai social media. Namun kendala yang terjadi di SMPN 2 Tanggulangin adalah dikarenakan mayoritas siswanya kurang mampu maka model pembelajaran ini tidak berjalan 
dengan baik, maka disaat perizinan untuk sekolah melakukan tatap muka terbuka peran mahasiswa untuk membantu para siswa untuk meningkatkan semangat belajar dan aktif kembali seperti sebelum adanya pandemi.

\section{DAFTAR PUSTAKA}

Amalia, N. F., Dayati, U., \& Nasution, Z. (2017). Peran Agen Perubahan Dalam Pelaksanaan Program Pemberdayaan Masyarakat Pesisir Pantai Bajulmati Kabupaten Malang. Jurnal Pendidikan: Teori, Penelitian, Dan Pengembangan, 2(11), 1572-1576. http://journal.um.ac.id/index.php/jptpp/

Anwar, S., \& Utama, W. (2014). Agen Perubahan (Agent of Change) Oleh: Syaiful Anwar / Widyaiswara Utama. Analisis Kebijakan Publik, 6(2), 5. https://kupdf.com/queue/akuntansisektor-publik_59cfa6cd08bbc54962686fdd_pdf?queue_id=-

$1 \& \mathrm{x}=1524533352 \& \mathrm{z}=$ MTIwLjE4OC4zNS4xNTA=\%0Ahttps://www.livemusikkommission.de /kulturraumschutz/agent-of-change/

Cahyono, H., Pendidikan, D., \& Inggris, B. (2019). agen. 1(1), 32-43.

Desmira. (2021). Sosialisasi dan Edukasi Protokol Kesehatan Bagi Masyarakat Desa. Dinamisia: $\begin{array}{llll}\text { Jurnal Pengabdian Kepada Masyarakat, } & \text { 5(2), 405-412. }\end{array}$ https://doi.org/10.31849/dinamisia.v5i2.5246

Ekowati, D. W., Astuti, Y. P., Utami, I. W. P., Mukhlishina, I., \& Suwandayani, B. I. (2019). Literasi Numerasi di SD Muhammadiyah. ELSE (Elementary School Education Journal): Jurnal Pendidikan Dan Pembelajaran Sekolah Dasar, 3(1), 93. https://doi.org/10.30651/else.v3i1.2541

Fristiohady, A. (2020). Peranan Peserta KKN Tematik Dalam Meningkatkan Kepatuhan Penggunaan Masker Pada Masa Pendemi Covid-19 di Kota Kendari. Dinamisia: Jurnal $\begin{array}{llr}\text { Pengabdian Kepada } \quad \text { Masyarakat, } & \text { 181-187. }\end{array}$ https://doi.org/10.31849/dinamisia.v5i1.4505

Idris, R. (2013). Pendidikan Sebagai Agen Perubahan Menuju Masyarakat Indonesia Seutuhnya (Education as an Agent of Change Towards a Complete Indonesian Society). Lentera Pendidikan, 16(1), 62-72.

Istichomaharani, I. S., \& Habibah, S. S. (2016). Mewujudkan Peran Mahasiswa Sebagai "Agent Of Change, Social Control, Dan Iron Stock." Prosiding Seminar Nasional Dan Call for Paper Ke-2 "Pengintegrasian Nilai Karakter Dalam Pembelajaran Kreatif Di Era Masyarakat Ekonomi ASEAN" 2016, 2-7.

Kementerian, \& Kebudayaan, P. dan. (2021). Kemendikbud Luncurkan Kampus Mengajar Angkatan 1 Tahun $2021.209 \quad$ Februari. https://www.kemdikbud.go.id/main/blog/2021/02/kemendikbud-luncurkan-kampusmengajar-angkatan-1-tahun-2021

La Ode Alis, Jamaluddin, dan S. R. (2018). Peran Mahasiswa Sebagai Social-Control(Studi Tentang Partisipasi Mahasiswa dalam Mengawasi Pengelolaan Dana Desa Di Desa Kondongia Kecamatan Lohia Kabupaten Muna). Neo Societal Jurnal, 3(2), 484-493. https://media.neliti.com/media/publications/246106-peran-mahasiswa-sebagai-socialcontrol-s-403c6387.pdf

Mulyo Teguh. (2017). Aktualisasi Kurikulum 2013 Di Sekolah Dasar Melalui Gerakan Literasi Sekolahuntuk Menyiapkan Generasi Unggul Dan Berbudi Pekerti. Prosiding Seminar Nasional , 18-26.

Neneng Zubaidah. (2021). Mengenal Kampus Merdeka dan Program yang Bisa Dipilih Mahasiswa. Selasa, 02 November. https://edukasi.sindonews.com/read/587470/211/mengenalkampus-merdeka-dan-program-yang-bisa-dipilih-mahasiswa-1635858663

Putri, L. D., Repi, \& Fitridawati Soehardi. (2018). Pemberdayaan Mahasiswa Fakultas Teknik Dengan Program Kreatifitas Mahasiswa (PKM). Dinamisia : Jurnal Pengabdian Kepada Masyarakat, 2(2), 315-321. https://doi.org/10.31849/dinamisia.v2i2.1184 